\title{
War Veterans, Fascism, and Para-Fascist Departures in the Kingdom of Yugoslavia, 1918-1941
}

\author{
John Paul Newman \\ National University of Ireland Maynooth \\ johnpaul.newman@nuim.ie
}

\begin{abstract}
This article discusses the role played by war veterans in the various fascist and parafascist groups present in Yugoslavia in the interwar period. The article finds that significant numbers of veterans and the nationalist associations to which they belonged contributed to proposed or actual departures from the democratic norm in interwar Yugoslavia, and were especially supportive of King Aleksandar Karadjordjevic's dictatorship of 1929-1934. In this respect, they could be termed 'para-fascist'. The article also notes that whilst the two groups typically identified in the literature as 'fascist', the Croatian Ustashe and Serbian/Yugoslav Zbor, fit into the 'second-wave' of 1930s fascist forces not usually marked by a strong presence of First World War veterans, their membership and ideological organisation were nevertheless significantly influenced by both the traditions of the war and the men who fought in it.
\end{abstract}

\section{Keywords}

Yugoslavia - fascism - Ustashe - Zbor - Aleksandar Karadjordjevic - ORJUNA National Defence - Chetniks - veterans

Comparative studies of European fascism have until recently tended to relegate Yugoslavia to the periphery. The two most obvious fascist candidates in Yugoslavia, the Croatian Ustashe and the Serbian/Yugoslav National Movement, or Zbor seem to fall into the category of fascist derivatives largely in the shadow of German National Socialism and Italian Fascism. Neither offered significant ideological or programmatic departures from the fascist mainstream in the way that Hungary's Arrow Cross or Romania's Legion of the Archangel

(C) NEWMAN, 2017 | DOI 10.1163/22116257-00601003 
Michael (the Iron Guard) did. Moreover, both the Ustashe and Zbor were marginal to the political culture of interwar Yugoslavia in size and in influence (it was not until the Second World War and the Axis occupation of the country that they were elevated to power and prominence). Elsewhere, the dictatorship of King Aleksandar Karadjordjević (reigned 1921-1934, as dictator from 1929-1934) has been understood as a manifestation of conservative authoritarianism, and therefore traditionally separated in the scholarship from fascism. Thus Yugoslavia had a 'little dictator' whose reactive illiberalism was not the same thing as the fringe radicalism of the Ustashe and Zbor. ${ }^{1}$

Things are starting to change, however. Firstly, a new generation of scholars, some publishing their work in the pages of Fascism, are starting to take Yugoslav fascism seriously and are producing illuminating works on the origins, evolution, and nature of groups such as the Ustashe, (to a lesser extent) Zbor, and their precursors. ${ }^{2}$ Secondly, there are new directions in fascism studies which, even when not directly concerned with local case studies, offer potential new perspectives on fascist tendencies and interactions in Yugoslavia. The key to moving beyond the existing impasse is to broaden the definition and the understanding of both what constitutes fascism and the way in which fascism interacts with the international political environment in interwar Europe. The work of Antonio Costa Pinto and Aristotle Kallis is especially useful in this respect, expanding Roger Griffin's concept of 'parafascism' so that it covers the range of 'post-liberal, hyper-nationalist, strongly anti-democratic and vehemently anti-socialist' political forces at large in the interwar period. ${ }^{3}$

1 See Antony Polonsky, The Little Dictators: The History of Eastern Europe since 1918 (London: Routledge and Paul, 1980).

2 On fascism in Yugoslavia, see the recent studies by Tomislav Dulić, Utopias of Nation: Local Mass Killing in Bosnia and Herzegovina (Uppsala: Uppsala Universitet, 2005); Maria Falina, 'Between "Clerical Fascism" and Political Orthodoxy: Orthodox Christianity and Nationalism in Interwar Serbia,' in Clerical Fascism in Interwar Europe, ed. Matthew Feldman, Marius Turda and Tudor Georgescu (New York: Routledge, 2008); Emily Greble, Sarajevo, 1941-1945: Muslims, Christians, and Jews in Hitler's Europe (Ithaca: Cornell University Press, 2011); Rory Yeomans, Visions of Anihilation: The Ustasha regime and the Cultural Politics of Fascism, 1941-1945 (Pittsburgh: University of Pittsburgh Press, 2013); Rory Yeomans, ed., The Utopia of Terror: Life and Death in Wartime Croatia (Rochester: University of Rochester Press, 2015); Alexander Korb, Im Schatten des Weltkriegs: Massengewalt de Ustasa gegen Serben, Juden, und Roma in Kroatien 1941-1945 (Hamburg: Hamburger Edition, März, 2013); Goran Miljan 'From Obscure Beginnings to State "Resurrection": Ideas and Practices of the Ustaša Organization,' Fascism, 5 (2016): 3-25, accessed February 21, 2017, doi:10.1163/22116257-00501002.

3 António Costa Pinto and Aristotle A Kallis, 'Introduction,' in Rethinking Fascism and Dictatorship in Europe, ed. Costa Pinto and Aristotle Kallis (Houndmills, Basingstoke, Hampshire ; New York, NY: Palgrave Macmillan, 2014), 2-3. 
Fascism in this sense is not an either/or property, which, say, the Ustashe and Zbor have and that other political forces in Yugoslavia lack, it is rather a 'destination' that typically starts with a 'departure', proposed or actual, from liberal democracy. ${ }^{4}$ This reconfiguration opens up an expanded 'grey zone' of 'cultural cross-overs between fascism and conventional authoritarianism' in which operate a variety of 'hybrid' political forces and groups. ${ }^{5}$ In Yugoslavia the grey zone of anti-democratic and illiberal forces and groups within the country was large indeed, and there are numerous points of para-fascist departure from the supposed norm of liberal democracy in Yugoslavia. Even so, the lure of fascism in the latter part of the 1930s, based elsewhere on the impressive successes of German National Socialism and Italian Fascism, was not strong in Yugoslavia.

Initial and brief observations about this problem can serve as prefaces to the lengthier discussion below. Take the Ustashe, they made full-blown territorial revisionism in the form of independence for Croatia a central tenet of their programme, in this way adhering to an eminently fascist principle. But such radical territorialism did not connect at a mass level with Croats in Yugoslavia, and the Ustashe never resolved the nettlesome problem of overlap between its own territorial aspirations and those of its most important sponsor, none other than Fascist Italy itself. As for Zbor, its leader Dimitrije Ljotić, despite being a decorated veteran of the Balkan and First World wars, was not agile enough to side-step the problem of hitching his party's fortunes to those of Germany and Italy. These states were revisionist powers par excellence, and Germany had been a wartime opponent of Serbia. Many Serbians who had fought in the conflicts of 1912-1918 (that is, the two Balkan wars and the First World War) found Zbor's international allegiances impossible to reconcile.

This brings us to veteran studies, the second point of intersection in this article. Comparative veteran studies have to a considerable extent been shaped by the cognate field of fascist studies. The understandable desire to explain the rise of right-wing politics and violence in the interwar period, and to trace it back to its apparent origins in the battlefields of the First World War, has led to a certain emphasis on the war experience as a facilitating factor of (especially right-wing) political violence in the interwar period. As the editors of this special edition remark, George Mosse's influential 'brutalisation' thesis, which argues that the war habituated soldiers to violence and barbarity and that these characteristics were carried over into the realm of

4 Aristotle Kallis "The "Fascist Effect": On the Dynamics of Political Hybridization in Inter-War Europe,' in Rethinking Fascism and Dictatorship in Europe, ed. Costa Pinto and Aristotle Kallis (Houndmills, Basingstoke, Hampshire ; New York, NY: Palgrave Macmillan, 2014), 17-18.

5 Kallis 'The "Fascist Effect", 16. 
peacetime politics, has continued to cast a long shadow over the study of veterans and the war experience. Only recently have historians began to fully explore the alternative routes and trajectories of veterans - in fact a majority who eschewed real and rhetorical violence in their collective and individual actions after $1918 .^{6}$

Such caveats apply to the Yugoslav case, too. There were, of course, veteran and nationalist associations committed to violent engagement in Yugoslavia, and these associations will be discussed at length below. But many of the veteran associations active in Yugoslavia in the interwar period were first and foremost committed to veteran care and welfare, especially for disabled veterans, or the families of soldiers who had been killed during the war, and (at least in the case of veterans of the Serbian army) commemoration of the war victory - their members had returned home without suffering any apparent 'brutalisation' as a result of their experiences in the war, or at least not in so far as it translated into political violence. ${ }^{7}$ This is not to say that they whole-heartedly embraced liberal democracy as the natural and rightful way of governing their country. As Alessandro Salvador and Anders Kjøstvedt have noted, very often the 'political dialectic between parties in the liberal democratic order were considered by veterans as discords dividing the people., 8 So it was in Yugoslavia, with even relatively benign and apolitical veteran associations and individuals bemoaning the paralysis and dysfunctionality of the parliamentary system in the $1920{ }^{9}{ }^{9}$ Although these associations were not para-fascist in their own right, their suspicion of liberal democracy lent them a certain sympathy towards authoritarian solutions to the country's political crises. ${ }^{10}$ And despite professing a disinterest in politics, many of these associations saw themselves as patriotic guardians

Antoine Prost and Jay Winter have used the biography of French veteran and jurist René Cassin as an archetype for this response to the war on the part of its veterans. See Jay Winter and Antoine Prost, René Cassin and Human Rights: From the Great War to the Universal Declaration (Cambridge: Cambridge University Press, 2013).

$7 \quad$ No study of war veterans and domestic violence has yet been undertaken in the Yugoslav case.

8 Alessandro Salvador and Anders Kjøstvedt, 'Introduction,' in New Political Ideas in the Aftermath of the Great War, ed. Alessandro Salvador and Anders Kjøstvedt (Cham: Palgrave Macmillan, 2017), xiii.

9 On this, see John Paul Newman, Yugoslavia in the Shadow of War: Veterans and the Limits of State-building, 1903-1945 (Cambridge: Cambridge University Press, 2015).

10 An example of this kind of veteran association would be the Serbian Association of Reserve Officers and Warriors, which was committed solely to its members welfare and to commemorating the war victory, but which nevertheless spoke critically about the government and its approach to the veteran question in Yugoslavia. On this association, see 
who could lead the country forwards in the postwar period, veterans 'tried to establish a unified and patriotic political order with themselves as the formative core.'11 Thus many Serbian veterans and their associations rallied around a 'culture of victory'12 - adopting an attitude of what we could term a 'patriotic statism' that sought above all else to protect the unity and the integrity of the new state, for which they had fought in the Balkan wars and the First World War.

But the legacy of war was more complicated still. Yugoslavia sat atop a fault-line of the war: many veterans had fought at various ranks and on various fronts in the Serbian and Montenegrin armies, and many more had fought in the Austro-Hungarian army, that is, on both the 'victorious' and 'defeated' sides of the war. For their part, South Slav veterans of the Austro-Hungarian army were more ambivalent about the categories of victory and defeat after 1918, but there was certainly a significant number who felt marginalised and alienated by the overwhelming public emphasis on victory in the new state. One of the most characteristic aspects of war culture in Yugoslavia is the way in which these various meanings of the war years, defeat and victory, interacted with one another to undermine postwar consolidation and to generate authoritarian potential within the state. As we shall see, both the Ustashe and Zbor reflect, in a highly idiosyncratic manner, the fracture between cultures of war 'defeat' (the Ustashe) and 'victory' (Zbor), even if they both fall into what Ángel Alcalde has in the Spanish context termed the 'second fascist wave' of groups that were founded in the 1930s and tended to be less influenced by war veterans than the 'first fascist wave' of the 1920 s. $^{13}$

The conflict itself in the Balkans must be understood in an expanded sense: it was not confined to 1914-1918, but in fact began with the first Balkan war of 1912 and extended well into the mid-1920s. The establishment of Yugoslavia at the end of 1918 was a demarcation point in this protracted period of war, rather than its end. Violence continued to smoulder in the contested borderlands of the new state: in Macedonia, Kosovo, Macedonia, Dalmatia, Carinthia; ${ }^{14}$ and

Danilo Šarenac, 'Udruženje rezervnih oficira i ratnika 1919-1941,' Istorija 20. veka 29, no. 1 (2011).

11 Salvador, Kjøstvedt, 'Introduction,' xiv.

12 John Horne 'Beyond Cultures of Victory and Cultures of Defeat? Inter-war Veterans' Internationalism,' in The Great War and Veterans' Internationalism, ed. Julia Eichenberg and John Paul Newman (Houndmills, Basingstoke, Hampshire; New York, NY: Palgrave Macmillan, 2013), 207-222.

13 Ángel Alcalde, 'War Veterans and Fascism during the Franco Dictatorship in Spain (1936-1939),' European History Quarterly 47 (2017), 89.

14 John Paul Newman, 'Post-imperial and Post-War Violence in the South Slav Lands, 1917-1923,' Contemporary European History 19 (2010): 249-265. 
in the hinterlands where Austro-Hungarian authority had largely broken down by the autumn of $1918 .{ }^{15}$ Subsequently, the process of disentangling the state's politics from violence and of demobilizing and removing war veterans from the state's political institutions was in many cases incomplete in the first half of the $1920 \mathrm{~s}$.

War veteran associations emerged throughout the country soon after the end of the First World War. In Yugoslavia, most of these associations were chiefly concerned with the social care of their members, especially the disabled and families of men killed in the fighting, as well as commemoration of the war itself. But a significant part of these war veteran associations flirted with rightwing politics and even with continued violence in the 1920s. Three of the most important of these associations, the Chetniks, National Defence, and ORJunA, contributed significantly to the undermining of liberal and democratic political consolidation in Yugoslavia, and can serve as examples of para-fascism in Yugoslavia in the 1920 .

\section{The Chetniks}

Some of the most ferocious violence in the post-1918 period took place in the so-called 'southern regions', Montenegro, Kosovo, and Macedonia, where rival groups would continue throughout the 1920 s to resist the Serbian/Yugoslav forces and their military auxiliaries. ${ }^{16}$ These territories had been zones of anti-Ottoman and intercommunal violence since the beginning of the twentieth century, fought over by Balkan national states (Bulgaria, Greece, Serbia, Montenegro) against the Ottomans, but also between rival Balkan states competing for influence in the region. ${ }^{17}$ Until 1912, this had been essentially a low intensity conflict waged by competing groups of irregular armed militias, socalled Četnici ('Chetniks', known to the Ottomans as Komitadji). ${ }^{18}$ More than

15 Ivo Banac, "Emperor Karl has become a Komitadji": The Croatian Disturbances of Autumn 1918,' Slavonic and East European Review 70, no. 2 (1992): 284-305.

16 Ivo Banac, The National Question in Yugoslavia: Origins, History, Politics (Ithaca: Cornell University Press: 1988), especially 291-327.

17 Mark Biondich, The Balkans: Revolution, War, and Political Violence since 1878 (Oxford: Oxford University Press).

18 The terminology is treacherous: the 'Chetniks' of the early twentieth century and the interwar period are not to be confused with the same-named royalist resistance 'Chetniks' led by Dragoljub Mihailović during the Second World War. See Jozo Tomasevich, The Chetniks War and revolution in Yugoslavia, 1941-1945 (Stanford: Stanford University Press), $115^{-121 .}$ 
simply a matter of military conquest and control the struggle for the Ottoman Balkans was also a struggle to shape and define the cultural identity of the regions in question, but violence was inseparable from attempts to nationalise both people and geography. ${ }^{19}$ The wars of 1912-1918 had enlarged the military dimension of these conflicts and forcibly changed the ethnic composition of the territories in question through ethnic cleansing and population removal. The victory of 1918 had given the Serbian forces the upper-hand (especially over defeated Bulgaria, Macedonian autonomists, and Albanian Kaçak bands).

The relationship between the state political and military forces of Serbia and Serbian Chetnik irregulars in this region was a complicated one. Although, as Mark Biondich points out, they were increasingly recruited and directed from Serbia proper in the years before the war, ${ }^{20}$ the Chetniks maintained the kind of political and military autonomy typical of Balkan militarist associations of the nineteenth and early-twentieth centuries. ${ }^{21}$ And despite fighting alongside the Serbian army in the Balkan wars and the First World War, the Chetnik modus operandi was significantly different from the regular army. The Chetniks were territorially based fighting forces, organised into small bands and typically under the sway of authoritative commanders, the Vojvoda [Field Marshal]. Chetnik veterans claimed that this form of organisation - small cells of dedicated fighters personally selected and known to the Vojvoda - resulted in an unusually high level of morale, ${ }^{22}$ a claim that was readily stereotyped in the considerable folklore surrounding the Chetniks and their role in Serbia's wars of 'liberation and unification'. ${ }^{23}$ Other commentators, on a spectrum

19 First-hand accounts of this phenomenon can be found in Stanislav Krakov, Plamen četništva (Belgrade: Vreme, 1930), and Stevan Simić, Srpska revolucionarna organizacija - komitsko četovanje u staroj Srbiji i Makedoniji 1903-1912 (Belgrade: Duška, 1998), On the Chetniks, Aleksa Jovanović, 'Četnički pokret u južnoj Srbiji pod Turcima,' in Spomenica dvadesetpetogodišnjice oslobođenje južne Srbije, ed. Aleksa Jovanović (Skopje:Južna Srbija, 1937).

$20 \quad$ Biondich, The Balkans, 45-93.

21 Dimitrije Djordjević, 'The Role of the Military in the Balkans in the Nineteenth Century,' in Der Berliner Kongress von 1878: Die Politik der Grossmächte und die Probleme der Modernisierung in Südosteuropa in der Zweiten Hälfte des 19. Jahrhunderts, ed. Ralph Melville and Hans-Jürgen Schröder (Wiesbaden: Steiner, 1982), 318-319. See also David MacKenzie, 'Serbian Nationalist and Military Organizations and the Piedmont Idea, 1844-1914,' in Eastern European Quarterly 16, no. 3 (September 1982): 323-343.

22 As an obiturist of Chetnik Vojvoda Jovan Stojković 'Babunski' put it 'His [Babunski's] komite were not soldiers, who took an orderly attitude towards their elders, they were more like brothers and comrades. His orders were not made in a high tone with furrowed brow and with threats, but in a friendly conversation over cigarettes'. In Vojnički glasnik, 28 June 1921.

Krakov, Plamen četništva. 
that encompassed Leon Trotsky through to the members of the Carnegie Endowment's International Commission on the Balkan Wars, claimed that the Chetnik volunteers were responsible for many of the worst atrocities that came to be associated with the Balkan wars of $1912-1913 .{ }^{24}$

After the First World War the Serbian/Yugoslav army initially continued to use the Chetniks in their capacity as military auxiliaries in the extended postwar operations in the south - because of the value of their local knowledge and expertise, but also because the Chetniks could operate unbounded by the strictures of conventional war, something that would have been difficult for the army itself. ${ }^{25}$ Thus, a 'free hand' to operate 'as you see fit' was extended to Chetnik leaders in the new state's euphemistically titled 'pacification' campaigns at the end of the war. ${ }^{26}$ Ultimately, this offer, taken up with enthusiasm by many Chetnik commanders, including the notorious Montenegrin Vojvoda Puniša Račić, ${ }^{27}$ was withdrawn by Belgrade, which sought to bring the military and political control of these territories under their own auspices as part of the larger state-building project after the war, offering instead Chetnik veterans parcels of land in the state's programme of internal colonisation (a programme for which the 'southern territories' were a key target). ${ }^{28}$

The Chetniks thus faced an existential crisis in the years after the end of the First World War, the question of purpose now begged itself to these veterans: their lives' work had been the liberation of Christian territories from imperial Ottoman rule, the wars of 1912-1918 had essentially achieved this goal; here, then, was the emptiness of a programme fulfilled. The Chetnik response was what we might term 'partial-demobilisation'. They re-emerged in the early 1920 as part-war veteran association, concerned with the social care of soldiers who had served with the Chetniks during the wars, as well as commemoration of the Serbian victory (and particularly the so-called 'Toplica Uprising'

24 Leon Trotsky, The Balkan Wars, 1912-1913: The War Correspondence of Leon Trotsky (New York: Pathfinder Press, 1980); Report of the International Commission to Inquire into the Causes and Conduct of the Balkan Wars (Washington DC: Carnegie Endowment for International Peace, 1914).

25 See Dmitar Tasić, Rat posle rata - Vojska Kraljevine Srba, Hrvata i Slovenaca na Kosovu i Metohiji i u Makedoniji 1918-1920 (Belgrade: Službeni glasnik, 2012).

26 Vasilije Trbić, Memoari, knjiga 1: 1912-1918 (Belgrade: Kultura, 1996).

27 Puniša Račić (1886-1944) was a member of the Montengrin Vasojević clan who served as a Chetnik in the Balkan wars and the First World War. He later turned to politics, and as a member of the People's Radical Party was elected into the national parliament in 1927 (see below).

Djordjo Krstić, Kolonizacija u Južnoj Srbiji (Sarajevo: Štamparija 'Bosanska pošta', 1928). 
of $1917^{29}$ ) - and part- political/paramilitary group with an ominous influence on the postwar politics of the new state.

When it came to national politics and national consolidation, the Chetniks were a house divided. Some Chetnik leaders believed the new state's national identity should be a matter of Serbian historical, political, and military traditions absorbing and assimilating those of the Croats and the Slovenes; ${ }^{30}$ others believed a new national identity needed to evolve, one that was based on a new Yugoslav culture. This, in fact, spoke to a larger division in the attitudes of many Serbian war veterans about the political path forwards for their nation after 1918, 'Greater Serbian' or 'Yugoslav'. Not incidentally, the two largest political parties in Serbia in the 1920s, the People's Radical Party and the Democratic Party, took opposing stances on this, with the Radicals adopting the 'Great Serbian' idea, and the Democrats pursuing a path towards 'Yugoslav' integration. ${ }^{31}$ In the first half of the 1920s, Kosta Pećanac ${ }^{32}$ and Ilija Birćanin, ${ }^{33}$ leaders of the majority faction in the Chetniks, were by conviction Yugoslavs (Pećanac even ran unsuccessfully as a DS candidate for the national parliament); whereas rival Vojvoda Puniša Račić was a member of the Radicals and a vocal proponent of the 'Great Serbian' agenda. These divisions were in large part a reflection of the ongoing rivalries between various Chetnik Vojvode.

There can be no doubt that the Chetniks believed in achieving political and national goals through the use of violence. Indeed, national work and violence

29 The 'Toplica Uprising' was a mass military revolt began in protest at attempts by the Bulgarian army to conscript Serbian men under occupation.

$30 \quad$ No other peoples were recognised as constituent in Yugoslavia.

31 Biondich, 'The Historical Legacy: The Evolution of Interwar Yugoslav Politics, 1918-1941', in Lenard J. Cohen and Jasna Dragojević-Soso, State Collapse in South-Eastern Europe: New Perspectives on Yugoslavia's Disintegration (West Lafayette, Indiana: Purdue University Press, 2008).

32 Kosta Milovanović 'Pećanac' (1879-1944) was a gerndarme and former reserve officer of the Serbian army who fought with the Chetniks from the end of the nineteenth century onwards, and as an irregular auxiliary of the Serbian army during the Balkan wars and First World War.

Chetnik Vojvode usually took noms de guerre inspired by the regions or parts in which they operated, thus Kosta Milovanović 'Pećanac' (of Peć, in the Kosovo vilayet), Ilija Trifunović 'Birčanin' (from Birč, in Hercegovina) Jovan Stojković 'Babunski' (from the Babuna mountains in Macedonia).

33 Ilija Trifunović 'Birćanin' (1877-1943) served as a Chetnik volunteer in the Balkan wars and the First World War. He led the patriotic association National Defence (see below) from 1932 onwards. 
had been entwined in the minds of the Chetnik leaders since the formation of the militias at the beginning of the twentieth century. The re-assertion of nationalist goals by the Chetniks was a response to the various challenges they perceived in the immediate postwar period, the continued violence in the region well into the 1920s, the ambiguous and often fraught relationship with state institutions such as the government and the regular army, the thorny matters of party politics and indeed the parliamentary system itself. Their association's relationship to national politics could be described as parasitical: rival Chetnik associations attached themselves to political parties as unofficial 'enforcers' at election time, holding the line against the state's enemies. But the Chetniks did not generate radical new political styles or programmes of their own - in ideological terms they were always junior partners to the parties themselves. In this sense, the Chetniks could be described as part of the parafascist web of political forces that undermined liberal politics in the 1920 sut that did not offer a full-blown, revolutionary agenda.

It is worth noting an additional point, perhaps specific to the Balkan states of interwar Europe. Yugoslavia's political DNA contained traces of numerous longer-term militarist and paramilitary traditions and institutions and irregular and semi-regular armed groups and associations, such as the Chetniks, many of which had roots that went back to the nineteenth century and the political and military struggles against empire. The memberships of such groups were expanded by veterans of the Balkan wars and the First World War, but even so, their roots remained in the often violent struggles of the nineteenth century Balkans. They fit well into the parafascist camp of anti-liberal and antidemocratic forces, but at the same time, they were perhaps too deeply-rooted in the nationalist anti-imperial traditions of the past to move decisively beyond these and into the realm of full-blown fascism. In other words, there was departure, but not destination.

\section{National Defence}

Narodna odbrana [National Defence], the patriotic militarist association based in Serbia but active in the Habsburg lands in the pre-war period, followed a similar path of postwar resurrection in the 1920s. Formed in 1908, in the wake of the anxieties caused by Austro-Hungarian annexation of the Ottoman province of Bosnia (Bosnia-Herzegovina), National Defence styled itself as a patriotic association dedicated to (Serbian) 'cultural work' in the province. National Defence was concerned with the ultimate reversal of the annexation through the establishment of a network of anti-Habsburg cells 
within Bosnia. ${ }^{34}$ The association had achieved considerable notoriety in 1914 when the Austro-Hungarian ultimatum to Serbia had erroneously identified it as directly responsible for the assassination of Archduke Franz Ferdinand in Bosnia (apparently mistaking it for 'Unification or Death' - the Black Hand - a group with which National Defence admittedly had numerous ties, see below).

National Defence also faced oblivion in the wake of victory - its purpose, the liberation and unification of South Slav lands into a single national state, achieved with the demise of Austria-Hungary in 1918. But like the Chetniks, National Defence soon re-surfaced, its leadership claiming that true 'cultural' unification - as opposed to simple political and institutional unification - remained unrealised in the troubled postwar period. National Defence posited that for the new state to succeed it needed to be animated by a culturally Yugoslav component. ${ }^{35}$ This new postwar project was, in a sense, a continuation of their pre-war work, in which National Defence's leaders continually claimed that their role in national life in Habsburg Bosnia was exclusively about the promotion of Serbian culture (rather than political and military work - in reality, National Defence pursued all these fields).

Although not a veteran association per se, a large component of National Defence's membership had served in the Serbian army and the Chetniks in the wars of 1912-1918. This was a consequence of their close ties with both the Serbian army itself and with other militarist associations. Many of the association's members were still active as soldiers or officers of the Yugoslav army after 1918, many were also associated with the Chetnik associations of the postwar period (Pećanac and Birćanin were both members). Like the Chetniks, National Defence was sceptical, even suspicious, of the parliamentary system within Yugoslavia, and the association quickly identified the divisions of party politics as one of the largest obstacles on the path towards authentic national unification. ${ }^{36}$ These illiberal tendencies, combined with the goal of national regeneration and an emphasis on the war years as an example for emulation, hint at the beginnings of a fascist programme. And indeed, the association's proposed departure from liberal democracy also made it open to the lure of Italian Fascism as early as the mid-1920s. National Defence discussed Fascist ideas with (not uncritical) admiration in the pages of its journal, praising in

34 Ljubodrag Dimić, Kulturna politika Kraljevine Jugoslavije 1918-1941, vol. 1 (Belgrade: Stubovi kulture, 1997), 467 .

35 Bogomir Bogić, Ciljevi Narodne Odbrane (Belgrade: Bogić, 1934).

36 Velibor Jonić, 'Narodna Odbrana,' in Naše selo, ed. Miloslav Stojadinović (Belgrade: Štampiranje "Tucović", 1929). 
particular the example set by Mussolini, a robust nationalist had cured Italy of the parliamentary sclerosis. ${ }^{37}$

Such fascistizing impulses were located at the very centre of the association, its leadership - but there was an even more radical fringe within the association's membership, consisting of nationalist intellectuals who would eventually grow impatient with the lack of revolutionary élan in National Defence and who would become leading lights of Zbor in the latter part of the 1930s. These were men such as Stanislav Krakov, a talented if dilettantish veteran of the wartime Chetniks who after 1918 dabbled in journalism (as editor of the nationalist newspaper Vreme in the interwar period), fiction (short stories and novels, usually about the wars), poetry, and even movie-making. ${ }^{38}$ Krakov conceived and directed a would-be epic feature film about Serbia's wars and revolution, For the Honour of the Fatherland (1929), an early landmark of Balkan cinema that spliced newsreel footage of the war with re-enacted battles (featuring a large cast of extras, actually soldiers serving the Yugoslav army leased to Krakov for the purposes of making his film). Krakov felt that cinema was the only medium sufficiently revolutionary to capture the essence of the war; ${ }^{39}$ his search for revolutionary new forms was carried over into the sphere of politics, too. Indeed, and as elsewhere in interwar eastern Europe, avantgarde art and politics went hand in hand..$^{40}$

National Defence did not possess the monolithic sense of ideology and political purpose necessary to embark upon a right-revolutionary political project. The association's relatively uncontroversial claim to be working towards the cultural unity of the South Slavs drew in members from across a wide spectrum: politically conservative army officers, Serbian patriots - the association even prided itself on breaking down the ethnic line by opening chapters in 'non-Serbian' cities, notably the Croat capital Zagreb (although the majority of National Defence's membership remained Serbian, or else Serbs from outside

$37 \quad$ Narodna Odbrana, 15 May 1926.

38 Krakov's papers in the Archive of Yugoslavia, Belgrade (Arhiv Jugoslavije Fond 102) are a rich and as yet largely untapped source on this intriguing and important personality of the Serbian interwar right.

39 A conclusion at which he apparently arrived after watching King Vidor's First World War epic The Big Parade. See Krakov's review in Srpski književni glasnik (1927) 2, 318-320.

40 Serbian author (and reluctant veteran of the Austro-Hungarian army) Miloš Crnjanski was a luminary of Belgrade's literary scene tempted by right-wing politics. See John Cox, 'Violence, Vienna, Versailles, and Venezuela: The Effects of World War 1 on the Nationalist Thought of Miloš Crnjanski,' in New Political Ideas in the Aftermath of the Great War, ed. Alessandro Salvador and Anders Kjøstvedt (Cham: Palgrave Macmillan, 2017), 25-40. 
of Serbia). National Defence was thus a broad church rather than a dedicated sect.

Other kinds of divisions cleaved into the group's membership. Importantly, National Defence included both remnants of Ujedinjenje ili smrt [Unification or Death] and its opponents. Unification or Death - known to its many enemies as the Crna ruka [Black Hand] - was formed in 1911 by a ring of active and reserve officers of the Serbian army, as well as civilian supporters and headed by Serbian chief of military intelligence, the notorious Dragutin Dimitrijević 'Apis.' ${ }^{41}$ The group's most important achievements were two fateful 'regicides': that of Serbian king Aleksandar Obrenović in a palace coup in Belgrade, 1903, and that of Franz Ferdinand, heir-apparent of the Austro-Hungarian monarchy, in 1914. The group had repeatedly strayed into the realm of civilian and national politics, and was eventually dealt a death blow by the parliament and the crown in 1917, when a rigged trial at Salonika (wartime location of the Serbian government and army) handed down a death sentence to Apis and other Black Hand ringleaders. ${ }^{42}$ The treatment of this group and its supporters divided the Serbian/Yugoslav army officer corps and militarist associations such as National Defence - divided, that is, between 'Black Handers' who had been members or else were supportive of the group, and those who were opposed to it. These latter were more loosely grouped around the rival 'White Hand', a court camarilla loyal to Aleksandar Karadjordjević that sought to push back against the influence of the Black Hand..$^{43}$ The leadership of National Defence seemed keen to heal this wound, bestowing the association's presidency onto Stepa Stepanović, ${ }^{44}$ an elderly, retired, and politically inactive commander of the pre-war Serbian army who had once been closely associated with the Black Hand. Stepanovićs largely honorific position as head of National Defence looks to be a reconciliatory gesture towards disgruntled former associates of the Black Hand itself.

41 David Mackenzie, The 'Black Hand' on Trial, Salonika, 1917 (Boulder: East European Monographs, 1995).

42 David Mackenzie, The Exoneration of the Black Hand 1917-1953 (Boulder: East European Monographs, 1998).

43 Banac, The National Question in Yugoslavia, 146.

44 Stepa Stepanović (1856-1929) was an officer of the Serbian army who served in the wars against the Ottoman empire (1876-1878), Bulgaria (1885), and in the Balkan wars and First World War, achieving the honorific rank of Vojvoda (Field Marshal, the highest rank in the Serbian army, obtainable only in battle). He served as Minister of War in the pre-war Serbian kingdom, and as president of National Defence from 1924 until his death in 1929 (see below). 
Stepanović, as we shall see, made National Defence a more passive force in the political life of Yugoslavia: critical of the shortcomings of the parliamentary system, instinctively illiberal, but unwilling as an association to move directly into the political sphere. This, accompanied by the association's pre-occupation with reconciling divisions of the pre-war period, inhibited National Defence's ability to move beyond parafacism's grey zone in the interwar period. More positive and creative in their approach to politics than the Chetniks, National Defence could nevertheless not alchemize its various ideological elements a single programme, nor, in the event, did the association show a willingness to supersede the existing political institutions of the state, despite its trenchant criticism of them. War veterans and the war were indeed at the heart of National Defence's postwar incarnation, but the war was typically seen as the culmination of Serbia's struggle for national emancipation, rather than ground zero for a new political project.

\section{ORJUNA}

A more radical assault on Yugoslavia's peaceable society came from the militant South Slav nationalist movement, the Organizacija Jugoslovenskih Nacionalista [ORJUnA; Organisation of Yugoslav Nationalists], formed in Split in 1921, with sizeable support on the Adriatic littoral (from Dalmatia to Trieste) and with branches across the country. ORJUNA was a paramilitary organisation comprising armed groups, often members of the 'war-youth' generation who had been too young to fight during 1912-1918, but backed up by war veterans who sought to defend the war victory from real and perceived enemies. ${ }^{45}$

The immediate cause for ORJUNA's formation was the assassination of Serbian politician Milorad Drašković by a militant communist group, 'Red Truth', in 1921. Anti-Communism thus formed a central tenet of ORJUnA's ideology, but local and regional concerns were also important. It was no coincidence that ORJUNA was founded in Dalmatia, a region from whence it drew much support: the Adriatic territories were sharply contested in the postwar period by rival territorial claims from Italy, and ORJUNA's mobilisation represented in large part a response to this threat. As Marco Bresciani has noted, there was a dialectical relationship between orJunA and the South Slav nationalist organisations along the Adriatic on the one hand and the Italian

45 On ORJUnA, see Branislav Gligorijević, 'Organizacija jugoslovenskij nacionalista (ORJUnA),' Zbornik Radova XX veka (1963). 
Squadristi on the other, and one way of understanding the group's identity and actions is by thinking of the Adriatic zone as a transnational space of violent ethno-nationalist and political confrontation involving Italian Fascists, Italian Socialists, and South Slav nationalist militias such as ORJUnA. ${ }^{46}$ ORJUNA also mobilised against supporters of Stjepan Radić's Peasant Republican Party (a confrontation that heightened after Radić's decision to run in Dalmatia in the national elections of 1923), and Croat nationalists, identified by ORJUNA (often erroneously) as 'Frankists' (see below).

The war and war veterans were central to ORJUNA's programme. ORJUNA sacralised the generation of Gavrilo Princip, assassin of Franz Ferdinand, as a nationalist vanguard prepared to lay down their lives for the Yugoslav revolution. ${ }^{47}$ ORJUNA also claimed a lineage with the wartime volunteer movement those South Slavs, either from the global diaspora or else Habsburg prisoners of war (mainly in Russia) who had volunteered to fight in the Serbian army in the First World War. ${ }^{48}$ Both provided orJuna with the example of a blood sacrifice that its members were required to emulate. And indeed, some of ORJUNA's skirmishes with its various enemies resulted in deadly violence, most notoriously a brawl with communist miners in Trbovlje, Slovenia, in $1924 .{ }^{49}$ War veterans themselves were not unified over the actions of ORJUNA in the early 1920s. The largest associations were often critical of ORJUNA's violence thus the 'Union of Volunteers', the veteran association that represented the former volunteers of the Serbian army that were so fêted by ORJUNA, complained about the nationalist association's attacks, even whilst supporting the group's ideas and commitment to Yugoslav unity. ${ }^{\circ}$ On the other hand, Chetnik leaders Kosta Pećanac and Ilija Birćanin were supportive of ORJUNA, seeing in the movement a significant crossover with their own Yugoslavism. ORJUNA repaid this compliment by making both men Veliki čelnici [High Leaders] of the

46 Marco Bresciani, "The Post-imperial space of the Upper Adriatic and the Post-war ascent of Fascist,' in Vergangene Räume - Neue Ordnungen: Das Erbe der multinationalen Reiche und die Staatsbildung im östlichen Europa 1917-1923, ed. T. Buchen and F. Grelka (Frankfurt a.d. Oder: Viadrina Universität, 2016). See also Boris Mlakar, 'Radical Nationalism and Fascist Elements in Political Movements in Slovenia between the two World Wars,' Slovene Studies 31, no. 1 (2009): 3-19.

47 The ideology and history of ORJUNA is set out in ORJUNA leader Niko Bartulovićs book Od revolucionarne omladine do Orjune: Istorijat Jugoslavenskog omladinskog pokreta (Split: Direktorium Orjune, 1925). It was also espoused throughout the pages of their largest journal Pobeda [Victory], published in Split in the 1920 .

48 Bartulović, Od revolucionarne omladine do Orjune, 59.

49 The brawl is discussed in Nova Evropa, 1 October 1924.

5o Rodoljub, 15 July and 22 July 1923. 
association, and Pećanac and Birćanin occasionally spoke at ORJUNA's rallies. ${ }^{51}$ There is, of course, an obvious parallel between the violent conduct of ORJUNA and the Chetnik associations that Pećanac and Birćanin represented.

A convincing case for ORJUNA's fascist credentials can and has been made. ${ }^{52}$ The organisation's leadership certainly embraced 'Yugoslavism' as a revolutionary ideology, claiming that its proper realisation would require a comprehensive remaking of society and the individual. ${ }^{53}$ Violence was central to this process of remaking, because the parliamentary system itself was an inhibitor of true national integration, allowing the kingdom to be imperilled by 'anti-State' forces such as Stjepan Radić, the communists, and the Italians. These points carried more force in the febrile atmosphere of the 1917-1923 period, and they were more than just rhetorical nods, ORJUNA frequently engaged in violence, and repeatedly called for dictatorship as a means of settling scores with the state's enemies.

\section{War Veterans and Parliamentary Politics, 1921-1929}

The membership and, especially, the leadership of these aforementioned associations harboured ambiguous attitudes towards the parliamentary system in Yugoslavia, an institution that did not fully succeed in detaching itself from the violence and divisions of the war years.

The avowed position of most veteran and nationalist associations in the 1920 s was essentially 'apolitical', meant in the sense that no official party political affiliation was brooked by the associations in question. The logic behind this decision seems to have been that the broader social and cultural concerns of the associations would be hindered through strict adherence to a party programme - veteran and nationalist associations instead called upon political parties to honour the compact between state and veterans in the postwar period, redeeming the blood sacrifice of the war through social care, commitment to commemoration, upholding the integrity of the new state, and so on. ${ }^{54}$

Yet this avowed indifference to party politics concealed a much deeper level of engagement. The leaderships and memberships of groups like the ORJUNA and the Chetniks had definite ideas about the national question and forging

\footnotetext{
$51 \quad$ Pobeda, 17 May 1924.

52 See, e.g., Stevo Djurašković, 'Ideologija Organizacije jugoslovenskih nacionalista (Orjuna),' Časopis za suvremenu povijest XLII/1 (2011).

53 Pobeda, 24 September 1921.

54 See, e.g., Glas ratnika, 25 September 1920.
} 
Yugoslavism in the postwar period, and certain parties and party leaders were identified as conduits of these ideological goals. Thus ORJUNA, whilst denying any kind of party political affiliation, were in reality close to the Croatian Serb politician Svetozar Pribićević, especially after the formation of his Independent Democratic Party (SDS) in $1924 .{ }^{55}$ ORJUNA felt kinship to the party and its leader on account of their shared and unwavering support for Yugoslavism and their hard-line against dissenting voices, especially that of Stjepan Radić and the Croatian Peasant Republican Party.

The Chetniks were similarly ambivalent. Whilst the association publically disavowed party politics, the leadership, at least in the first half of the 1920s, was favourably disposed towards the Democratic Party of Ljubomir Davidović. Davidović had been president of the Chetniks' cultural branch in the pre-war period, and he remained a prestigious figure in the postwar organisation. ${ }^{56} \mathrm{But}$ there was another significant faction in the Chetniks, headed by Puniša Račić, that sought to transform the Chetniks into a 'Great Serbian' association. Račić was himself a member of the Radical party and successfully stood on its list in the elections to the Constituent Assembly in 1920, and again in the national elections of 1927.

The relationship between veteran associations and the representative political institutions of the state was even more complicated still. For many veteran associations, irrespective of their attitudes towards individual political groupings, the parliamentary system was identified as a corrosive influence on national unity. The dysfunctional way in which governments were formed and unformed, and political deals were made and broken, seemed to inhibit a true sense of national and cultural unification across the South Slav lands. Many veterans expressed impatience at the manner in which politicians and political parties were unable to establish and maintain a meaningful and lasting means of governing the country. Veterans were displeased at the inability of the parliamentary system to effectively legislate for social care for disabled former soldiers or were critical of the manner in which veteran verification certificates were forged and passed out in order to curry political favour or to win votes. ${ }^{57}$ But these criticisms often fed into a more generalised impatience with the ways and means of parliamentary politics itself. Thus many veterans disliked the processes of compromise and deal-making intrinsic to effective coalition building and governing. In this sense, valid criticisms of the flaws of

55 Gligorijević, 'Organizacija jugoslovenskih nacionalista (ORJUNA).'

56 The Democratic Party, with its Yugoslavist platform, received the support of both Ilija Birćanin and Kosta Pećanac.

Milivoje Erić, Agrarna reforma u Jugoslaviji 1918-1941 (Sarajevo:Veselin Masleša, 1958), 247. 
Yugoslav party politics strayed into criticisms of liberal politics per se. An acceptance on the part of veterans of parliamentary democracy as an inviolate principle of political organisation is not evident.

Perhaps even more seriously, veterans were concerned about the way in which the parliamentary system allowed what they termed 'anti-state' factors into the political life of the country, thus, again, threatening the integrity of the state itself. 'Anti-state' was primarily taken to mean Stjepan Radić and the Croat Peasant Republican Party, although it also came to encompass those political parties and leaders who sought compromise with Radić in the first half of the 1920s. Serbian veteran associations were concerned about Radić's consistently anti-militarist and anti-army rhetoric, underscored by his repeated - and frequently heeded - calls for Croats to ignore the army's conscription efforts. Radić had arrived at a very different understanding of the war years than those who supported the ideas of 'liberation and unification': for him, the First World War had been a clash of oppressive empires fought by unwitting conscripts, the lesson was that no Croat soldier would ever fight again in a 'foreign army'. 'Foreign' had meant the Austro-Hungarian army, but after 1918 it came to mean the army of Yugoslavia. ${ }^{58}$

War veterans had considerably more respect for Aleksandar Karadjordjević, Yugoslav king (after the death of his father Petar) from 1921 onwards. Aleskandar's relationships with veterans and with the army on the one hand and with the parliamentary system on the other are crucial to understanding the course of politics in Yugoslavia in the 1920s. The crown and Aleksandar emerged almost unequivocally as symbols of prestige and power amongst war veterans in the postwar period. Aleksandar was the 'unifier' who had led the Serbian army in the wars of 1912-1918, and he therefore remained the warriors' champion in the postwar period. Veterans looked towards Aleksandar as a symbol of national unity, a talisman of the war years. Aleksandar himself returned the favour by offering material and financial support to veteran associations, and by frequently appearing at their public parades and events. But at the same time, Aleksandar seems to have shared with his veterans at least an impatience with the problems of parliamentary politics: the Yugoslav constitution called for Aleksandar, as head of state, to assume the role of arbiter between political parties, but he interpreted this role generously - laying an increasingly heavy hand on the various governing coalitions in Yugoslavia, directing parties towards his own preferences and asserting himself into the process of coalition building. ${ }^{59}$

$5^{8}$ See Rudolg Herceg, Svjetski rat i problem nove države (Zagreb: Naklada tiskara Ign. Granitz, 1919).

59 On Aleksandar's 'autocratic tendencies' see Dejan Djokić, Yugoslavia Elusive Compromise: A History of Interwar Yugoslavia (London: Hurst and Company, 2007). 
The relationship between the national parliament, the army and war veterans, and Aleskandar himself is complicated and indeed still partially obscured by a deficit of historical sources and scholarly research. We can say with some confidence that Aleksandar was sceptical and impatient of liberal democracy in Yugoslavia, harbouring misgivings about the supposed democratic norms that obtained in postwar Europe. If not a congenital dictator, he was certainly amongst those who thought that 'Individual liberal democracy was not necessarily the privileged goal of history.' ${ }^{\prime} 0$ This was at the heart of many of his clashes with Yugoslavia's politicians.

So much for the relationship between the king and his parliament. The relationship between the king and war veterans (and the Yugoslav army) was more complicated still, and it is perhaps helpful to think of this as a two-way street. War veterans themselves, as we have seen, were wary of parliamentary democracy - and in this attitude found common ground with Aleksandar, a much more obvious symbol of national unity and patriotism. As for the king, there can be little doubt that much of his confidence in dealing with the country's civilian politicians derived from the tacit, or often not so tacit, support he received from the Yugoslav army and militarist and veteran groups in the country, a postwar convergence that made the likelihood of an authoritarian solution to the country's political problems, one supported by war veterans and the military, a real possibility. The history of military coups in the Balkans, many of them resulting in the toppling of crowned heads, shows the essential need to keep the army and its supporters on side.

The difficulties of political life in Yugoslavia were ensured at the outset following the deeply contested passing of the country's first constitution, the so-called 'Vidovdan Constitution', in 1921. The centralising principles of the constitution, at odds with the diversity of political and historical traditions in the country, ensured 'hard opposition' from the very beginning. ${ }^{61}$ The bulk of this so-called hard opposition came from the Croat Republican Peasant Party and its leader Stjepan Radić who, in rejecting the constitution, was quickly branded a potential enemy of the state, against whom the country's strict antistate legislation was readily invoked.

ORJUNA provides a case study of this elision of supposed anti-state forces in the immediate post-Vidovdan period, and also a case study in the extreme measures that some war veterans were willing to take in order to oppose it. As we have seen, ORJUNA was formed in the wake of the political assassination of Milorad Drašković by a communist fringe group in 1921. For ORJUNA, the lesson

6 David Roberts, Fascist Interactions: Proposals for a New Approach to Fascism and its Era, 1919-1945 (Oxford: Berghahn, 2016), 5.

61 Banac, The National Question in Yugoslavia. 
of the Drašković assassination was that violence needed to be met with violence in the fraught postwar years. ORJUNA carried into peacetime the symbols of the war years, depicting their own violent struggles in continuity with the wars of 1912-1918. But this force could be applied to all potential enemies of the Yugoslav state, including, of course, Radić. ORJUNA violence only intensified in the years immediately after the war, as Radićs electoral popularity amongst Croats grew, and his party decided to present candidates in Dalmatian towns and cities in the 1923 elections. This brought him into direct confrontation with ORJUNA, who used violent means to threaten and intimidate supporters of the peasant party in territories they looked upon as their own strongholds. ORJUNA's answer to this threat was to call for the abandonment of parliamentary democracy in toto - since it allowed unconstitutional and anti-state forces into national politics. Already, at this early stage, ORJUNA were calling for a royal dictatorship to resolve the problems of the postwar period. ${ }^{62}$

The involvement of nationalist veteran associations was even more widespread in the election campaigns and crises of 1923-1925. Some brief background is required to understand what was at stake in the country during these years. The national elections of 1923 shifted the electoral landscape in the country, it was the first time in the short history of Yugoslavia that the Radical Party had insufficient support to form a government as majority partner. A government was instead formed by Ljubomir Davidović and the Democratic Party. Davidović sought a reconciliation with Stjepan Radić and the Croat Peasant Republican Party - beginning talks with peasant party leaders and seeming to offer them a way into government. For Davidović this important new departure in national politics was a response to the disunity in the state: it was time, claimed Davidović, to break down the internal borders in Yugoslav society between the war's 'victorious' and 'defeated' parties - including Radić in his government was a means of moving beyond the cultures of victory and defeat that had wracked the country up until then, it was essentially a means of demobilizing Yugoslav society. In this way, the legacy of the war became central to the debates about politics and government in 1924 .

This attempted new course was undermined by numerous parties: the notion that Radić, who had until that point launched furious verbal attacks on the key institutions of liberation and unification: the crown and the army, might now be allowed into government, was unacceptable to many. The associations mentioned in this article all bristled at the prospect of the culture of victory becoming diluted by Davidović's rapprochement. Thus Chetnik 
support for Davidović, erstwhile president of the pre-war association, diminished precipitously, giving Puniša Račić the opportunity he had long sought to capture the group's leadership and steer it towards the 'Great Serbian' ideology of the Radical Party (whose leaders also opposed Davidović's move). ORJUNA also stepped up on their rhetorical attacks on Radić and the government itself. As for National Defence, this association was divided only in its position vis-à-vis the king and the army, two institutions that increasingly looked as if they would step in to settle the political crisis caused by the Davidović-Radić rapprochement. National Defence was torn, it seems, between a White Hand faction who favoured active support for the king should he step in and dissolve the faltering government, and a Black Hand faction that favoured a passive response both to the crisis itself and to a potential royal solution. Branislav Gligorijević has noted how certain factions of the officer corps began at this time to assist in the arming of militarist and nationalist groups such as the Chetniks and orJuna, with a view to using them in a potential conflict, of undetermined scale, but presumably fought between those who supported the king and the Great Serbian forces and those who supported Davidović and his followers. ${ }^{63}$

The Democratic Party leader's government eventually fell, after little more than one hundred days, following the withdrawal from government of the Minister for the Army and the Navy, Stevan Hadžić, a move almost certainly orchestrated by the king himself. The '100-Day' crisis of Ljubomir Davidović's government revealed the limits of liberal politics and Yugoslav political culture in the South Slav State. War veterans of the Serbian army were as yet unwilling to allow a change in national politics that would lead to any kind of diminishment of the Serbian 'culture of victory'. It was not only that Radić remained beyond the political pale on account of his anti-state rhetoric and stances on the king and the army - it was also that Davidović threatened to move on from the traditions of the war years. In the context of war veterans and politics in Yugoslavia, this battle of wills was pivotal.

The following election campaign foregrounded the history of the war years, and was fought by the Radicals and by Pribićević's newly-formed Independent Democrats as a defence of the values of the war against anti-state enemies such as Radić and Davidović. But the war was not only a rhetorical presence in the electoral campaigning: for the first time, there was a marked presence of 'electoral terror' at the ballot box, as associations such as ORJUNA and (especially) those factions of the Chetniks loyal to Puniša Račić sought to intimidate

63 See Gligorijević, 'Uloga vojnih krugova u "rešavanju” političke krize u Jugoslaviji 1924. godine,' Vojnoistorijski glasnik, 1, godina XXIII (January-April 1972). 
political opponents through the use of violence. ${ }^{64}$ The new atmosphere was noted by various observers, ${ }^{65}$ and it would now become a continuing factor in Yugoslav politics going forwards. It marked the moment when certain associations and war veterans translated their hostility about the parliamentary system from words into action. It also marked the realisation of the close ties between Aleksandar and his war veterans, which had until this stage in the state's life been primarily of festive or commemorative importance, but could now be reckoned upon as a source of real political power in the country. No longer was there any ambiguity about where the army and the militarist associations stood: they would back the king against potential enemies, should the need arise. Yugoslav parafascism now had a military component.

The coup de grace of these intersections between war veterans, national politics, and the king himself came in the summer of 1928, and was delivered by none other than Puniša Račić. Račić had been elected to the national parliament on the Radical Party list in the elections of 1927, continuing an ongoing pursuit of politics going back to the beginning of the South Slav state's life. He remained belligerently opposed to the Croat Peasant Party and its deputies, who had carried out something of a volte-face since the mid-1920s, abandoning the republicanism of their earlier years and agreeing, at least in principle, to work within parliament as a loyal opposition to the government. When, during a heated parliamentary session in the June 1928, a Croat Peasant Party deputy accused Račić of using the cover of his Chetnik activities during the war and immediate postwar years to steal from the civilian population, Račić demanded an immediate apology. Since this apology was not forthcoming, Račić, who attended parliamentary sessions armed, drew his pistol and fired at peasant party deputies, killing two instantly and wounding three more, including party leader Stjepan Radić, who died some weeks later from his wounds.

This assassination resulted in yet another political crisis, this time the most severe the state had faced since the end of the war, and one that was ultimately resolved by the king's suspension (permanent, as it turned out) of parliament and the installation of a royal dictatorship in January 1929, a move that was wholeheartedly supported by war veteran associations of the Serbian army. ${ }^{66}$

War veterans and their associations played an important role in the tortured political history of Yugoslavia in the 1920s - their involvement in party politics frequently amounted to bringing a violent fringe to the electoral processes

\footnotetext{
64 Nusret Šehić, Četništvo u Bosni i Hercegovini (1918-1941): Politička uloga i oblici djelatnosti četničkih udruženja (Sarajevo: Akademija nauka i umjetnosti Bosne i Hercegovine, 1971).

65 See, e.g., Ivan Ribar, Politički spisi, vol.1 (Belgrade: Prosveta, 1948), 161-162.

66 See, e.g., Ratnički glasnik, January 1929, and Vojnički glasnik, 9 January 1930.
} 
in the country. Their scepticism about the ability of the liberal system itself to reconcile difference across the country and, most importantly, to achieve Yugoslav unity, further undermined the consolidation of the parliamentary system. The real and rhetorical violence of the war years stalked the politics of the country throughout the postwar decade, most graphically and literally in Račić's act of political assassination in 1928, but this was only the sensational culmination of a history of embattled and often brutalised political discourse.

\section{The Dictatorship Years}

King Aleksandar's dictatorship had a number of seemingly contradictory effects on the veteran question and politics in interwar Yugoslavia. In the short-term the suspension of parliament was greeted across the country with relief - few people mourned the faltering parliamentary system and its decade of paralysis and failures. The king recognised the potent symbolism of the war and the role of war veterans as a pillar of his dictatorship, although he also seemed to realise that the war was fractious and disputed territory. In keeping with his overarching aim of accelerating the process of 'Yugoslavizing' the country Aleksandar consolidated the previously divided veteran and nationalist associations. ${ }^{67}$ The various Chetnik associations were re-organised into a single officially sanctioned group, the 'Association of Chetniks'; ORJUnA, an association whose violence had made it odious even to ideological and political supporters, was banned outright; National Defence was allowed to continue and repaid the king by announcing its support for his dictatorship. ${ }^{68}$

As we have seen, veteran associations and their leaders had from an early stage looked upon the king as a symbol of the national unity and prestige. Calls for the king to step in and take control of the state had been voiced throughout the 1920s, at times in very specific terms, such as ORJUNA's demands in the mid1920 to scrap the parliamentary system and introduce a royal dictatorship that could properly deal with the state's many opponents. The enthusiastic greetings given by these associations to the installation of the dictatorship, at least at its outset, can be read as genuine expressions of support on the part of the majority of war veterans.

King Aleksandar's dictatorship represented the coalescence and the culmination of illiberal tendencies that had been at large in Yugoslavia in the

\footnotetext{
67 See Christian Axboe Nielsen, Making Yugoslavs: Identity in King Aleksandar's Yugoslavia (Toronto: University of Toronto Press, 2014).

68 Narodna odbrana, 26 January 1930.
} 
1920 - the merging of Yugoslavia's various para-fascist forces and the final departure from the course of liberal democracy in Yugoslavia. The understandably hostile socialist-era historiography typically referred to the king's political project as 'Monarcho-Fascist', identifying Aleksandar as a Bonapartist figure who temporarily mobilised cross-class support for a militarist dictatorship. But this is to overstate the case: the dictatorship was essentially a product of the uncertainties and the political insecurities of the 1920s, the unwillingness of many parts of the Yugoslav state and its society to accept liberal democracy as the immutable facts of political organisation.

War veteran associations took this further: their instincts in the 1920s had been trenchantly statist, their mobilisation based around deeply-held fears of anti-state forces undoing the war victory by breaking up the state. This support was in turn galvanised by the charismatic authority of the king himself, identified by Serbian veterans as a central figure in the war's mythology. And this support was, of course, more than simply rhetorical: the 1920 had seen an ever closer convergence of interests and support between the king and militarist associations, as well as the army himself. In this respect the relationship between Aleksandar and an influential, all-powerful group of veterans and army officers resembled the relationship between Józef Piłsudski and his legionaries, or indeed that of Tomáš Masaryk and the largest Czech Legionary associations. For many veterans, there was also the revolutionary promise of the Yugoslav programme itself. We have seen how members of ORJUNA, or indeed National Defence, conceived of South Slav unification as a political, social, and cultural transformation of society and the individual, one that could be forced through by violent means if necessary. Aleksandar's project was (mis-)guided by this totalizing conception of Yugoslavia, the desire to break cleanly with the divisions of the past and push through a new political and cultural identity.

There are here seeds of the fascist project, but ultimately Aleksandar's authoritarian project owed more to the perceived weaknesses of politics in the 1920 s than it did to the surge of radical right politics and movements in the 1930s. The 'gravitational pull' of international fascism was not strongly felt in Yugoslavia in the second decade of the interwar period. The important exceptions to this rule are discussed below.

\section{The Ustashe}

Aleksandar's project had a ricochet effect on a small group of Croat nationalists who had been opposed to South Slav unification from the very beginning transforming them into full-blown paramilitary terrorist organisations that 
were intent - and in the event successful - on bringing the king's rule to an end. In the years of revolution and counter-revolution, 1917-1923, small groups of former Habsburg officers and Habsburg loyalists of mainly Croat descent had formed émigré and domestic groups whose quixotic goal was to break apart the Yugoslav state. Politically, they were guided by the leaders of the Čista stranka prava [Pure Party of Right], a small party that had been closely allied to Habsburg Vienna until the very end of the war, and with limited support amongst certain social strata, mainly in Zagreb. The followers of the Pure Party of Right were known colloquially, to opponents and allies, as the Frankovci [Frankists], after the renegade founder of their party, Osijek lawyer Josip Frank. ${ }^{69}$

The Frankists had loitered at the edges of Croatian national politics in the 1920s, remaining a negligible force in comparison to the mass movement of Stjepan Radić's Croat Peasant Party. The installation of Aleskandar's dictatorship sent the leadership of the Frankist opposition, at this time headed by Zagreb lawyer Ante Pavelić ${ }^{70}$ and journalist and former Austro-Hungarian officer Gustav Perčec, into exile (Hungary) to raise support and arms against Yugoslavia. They formed the 'Ustasha Croatian Revolutionary Movement' (the Ustashe) at the beginning of 1930, a paramilitary terrorist organisation that plotted to instigate a Croatian national uprising against Aleksandar's regime. A network of like-minded groups, of varying size, but all committed to territorial revisionism in the region, provided material and morale support. ${ }^{71}$ In exile, and with support from sympathetic factions at home, the Ustashe at first conducted small-scale acts of terrorism against Yugoslavia in the hope of sparking a mass uprising. These included the bombing of passenger trains passing through Yugoslavia, or attacks on Yugoslav border posts and police stations, most notably in Lika in 1932. When these tactics failed to yield meaningful results, the Ustashe moved to political assassination, scoring a sensational success in October 1934 with the assassination of Aleksandar himself, whilst the king was on a state visit to France.

Fascist Italy cultivated this group as a means of leverage against the Yugoslavs, and the collusion with this state, as well as the rise to power of

69 On the Frankists, see Banac, The National Question in Yugoslavia, 260-269.

70 Ante Pavelić (1889-1959) was a Zagreb lawyer who rose through the ranks of the Frankists in the 1920s, serving first on the Zagreb municipal council and then in the national parliament as a deputy (from 1927 onwards).

71 On the formation of the Ustashe, see Mario Jareb, Ustaško-domobranski pokret: Od nastanku do travnja 1941. godine (Zagreb: Školska knjiga, 2006). And Goran Miljan 'From Obscure Beginnings to State "Resurrection".' 
National Socialism in Germany, would define the political programme of the Ustashe. The Ustashe were especially susceptible to the process of 'fascistization' in the 1930s, culminating in its adoption of fascist politics and structures when the small group assumed control of the Independent State of Croatia following the defeat of Yugoslavia in 1941. The 'domestic' context of opposition to Yugoslavia in this way meshed with the larger and emboldened forces of illiberalism, revisionism, and fascism in 193os Europe.

The ideological nucleus of the Ustashe derived from the Croat Pure Party of Right and the context of Habsburg politics in the nineteenth and early twentieth century. ${ }^{72}$ The followers of Josip Frank had asserted that only the Croats constituted a 'political nation' on the territory of Croatia, a stateforming appellation that was significantly denied to the Serb minority in the same territory (in the Habsburg context, they were a 'non-political people'). This precept had evolved overtime into an increasingly chauvinistic and Serbo-phobic platform, informed by the Habsburg defeat of 1918 (blamed on Serbian nationalists) and the formation of Yugoslavia (identified by Frankists as a cover for 'Great Serbia'). In the 1930s, these ideas were compounded with the racialism of Fascism and Nazism - reaching a crescendo of annihilationist violence when the Ustashe took power in $1941 .{ }^{73}$ Their aim, immediately pursued, was to rid their new state of Serbs, Jews, and Roma by genocidal means.

The Ustashe's connection to war veterans is an intriguing one. Although strictly speaking a 'second-wave' fascist group that emerged in the 1930s, and thus less likely to include significant numbers of war veterans, the Ustashe, as we have seen also had a connection to postwar wave of counter-revolutionary violence that swept over Europe in the years after the end of the First World War. The war - and Habsburg war veterans - were of important to the Frankists and, subsequently - to the Ustashe. In the first place, the Frankists cultivated an alternate 'culture of defeat' that ran in opposition to the ruling culture of victory in Yugoslavia. For the Frankists, the war had resulted in the triumph of a most virulent and chauvinistic form of Serbian nationalism, the kind that had heedlessly led Europe into war in 1914. The Frankists had in the 1920s cultivated an alternate martyrology that emphasised the heroes of Croatian national history, as well as the 'war dead' of 1914-1918, Croat soldiers who had been killed fighting for Austria-Hungary against Serbia. This in turn was sacralised/ritualized by regular visits to Mirogoj cemetery in Zagreb, where the Frankists and their

\footnotetext{
72 On this context, see Stjepan Matković, Čista stranka prava 1895-1903 (Zagreb: Hrvatski institut za povijest i Dom i svijet, 2001).

73 On Ustaša racial policy, see Nevenko Bartulin The Racial Idea in the Independent State of Croatia: Origins and Theory (Leiden: Brill Academic Publishers, 2013).
} 
followers invoked the spirits of Croatia's fallen, and promised to avenge them in the future. ${ }^{74}$

Croat war veterans, too, played a role in the Frankists' imagining of Croatia's national future. The political group had always attracted a contingent of Austro-Hungarian officers of Croat descent, either as members or as followers, who supported the Frankists' loyalty to the monarchy and their hostility of Serbia and Serbian nationalism. At war's end, the political and institutional changes wrought by the unification of Yugoslavia left many of these officers at odds with the new regime. Although the newly-formed Yugoslav army tried, and in many cases succeeded, in drawing former Austro-Hungarian officers into the fold, many more remained unreconciled and opposed to the new state and its institutions. ${ }^{75}$ The Frankists, with their anti-Yugoslav liturgies and homilies to Croatian imperial military traditions, offered disgruntled former officers a political outlet. Once the Frankists graduated into the Ustashe, the paramilitary programme of the new group gave former officers an opportunity to practice once again the military craft, training soldiers in the Ustashe's émigré camps for the upcoming battle against Yugoslavia. Ante Pavelić repaid this support by placing former officers at the heart of his group - and using them in his armed forces in the Independent State of Croatia (especially in the Domobran home army). ${ }^{76}$

The presence of Austro-Hungarian veterans in the ranks of the Ustashe provides a suggestive causal link between the violence of the First World War in the Balkans and that of the Second. The German occupiers were certainly cognizant of the connection and its potential use in shoring up support for the Ustasha state (support that dwindled rapidly as the group launched a campaign of violence from the beginning of its rule in 1941). The German plenipotentiary in the Nezavisna Država Hrvatska [NDH; Independent State of Yugoslavia] was none other than Edmund Glaise-Horstenau, erstwhile Habsburg officer who had served as director of the military archives in Vienna in the interwar period. The Ustashe itself presented certain aspects of the new state as a kind of Habsburg revival, saluting the military traditions that had been disavowed in

74 The sacralisation of Ustaša politics is discussed in Stjepan Kljaić 'Apostles, Saints' Days, and Mass Mobilization: The Sacralization of Politics in the Ustasha State,' in The Utopia of Terror: Life and Death in Wartime Croatia, ed. Rory Yeomans (Rochester, Woodbridge: University of Rochester Press, 2015).

75 Hrvoje Čapo, 'Broj primljenih časnika bivše austrougarske vojske u vojsku Kraljevine Srba, Hrvata, i Slovenaca,' Časopis za suvremenu povijest 3 (2008).

${ }_{76}$ See Fikreta Jelić-Butić, Ustaše i Nezavisna Država Hrvatska 1941-1945 (Zagreb: Školska knjiga, 1977), 114-122. 
Yugoslavia. Thus, new and laudatory military histories of Croatia emerged, the prestige of Frontkampfer such as Freiherr Stjepan Sarkotić, wartime governor of Habsburg Bosnia, was duly acknowledged. ${ }^{77}$

However, beneath these official homilies the truly fascist aspect of the Ustasha programme appeared to bristle with veterans of the Austro-Hungarian army. The various military formations of the NDH were often split over matters of violence against civilians and the conduct of war. Split, that is, between a younger cohort fully committed to the Ustashe's fascist revolution and an older group who saw this new programme of violence as a radical departure from the Habsburgs' war of 1914-1918. This was the difference between a conservative, imperial military ethos, a legacy of Austria-Hungary, and that of a revolutionary fascist movement, the Ustashe. In comparative terms, it is notable that Pavelić never made a decisive reckoning with these non-revolutionary currents in his group, in the manner of the Nazis' 'Night of Long Knives', instead, piecemeal purges and killings - such as that of Gustav Perčec in 1934 or of Slavko Kvaternik in 1943, are evidence of an ongoing tension between various ideological currents within the Ustashe. Thus, the Austro-Hungarian connection was sufficient to forge an alliance of right-wing Croat nationalists against the Yugoslav state in the 1920s and even into the 1930s, but as the political core of the Ustashe went ever further towards the fascist programme, so the differences between the old and new guards became ever more pronounced.

\section{Post-dictatorship Years 1934-1941}

The final phase in the political life of Yugoslavia lasted from after the death of Aleksandar in 1934 until the collapse of the state in 1941. This phase was marked on the one hand with a renewed sense of despair at the failures of South Slav state and national integration, which had now proved incapable of taking hold in both the period of parliamentary democracy and in the dictatorship years. Aleksdandar's death in 1934 had brought to an abrupt end a political project that had been failing for some time and, as we have seen, had further alienated and radicalized opposition to the state. ${ }^{78}$ Aleksandar's death also opened the gates to a more critical stance on the part of Serbian veteran and patriotic associations towards the failures of the state, as well as a heightening sense of anxiety about the divisions within Serbdom itself, divergent attitudes towards

77 Slavko Pavičić, Hrvatska ratna i vojna povijest (Zagreb: Nakladničko trgovačko društvo Mato Lovrak, 1998).

${ }_{7} 8$ This thesis is elaborated in Nielsen, Making Yugoslavs. 
the Yugoslav project and its relationship to Serbian national integration, and intergenerational splits between war veterans and a new cohort of Yugoslavs who had been too young to experience combat and service during 1912-1918. All of this unfolded in a continent sliding once again into conflict.

The Chetnik associations, partially reined in by Aleksandar during the dictatorship years, were already straining at the leash in the months before the king's assassination, their leaderships growing impatient, and divided, over faltering attempts to remould society along Yugoslav lines. Pećanac and Birčanin, who had been closely allied in the 1920s, had also drifted apart, and taking their veteran constituencies with them as they went their separate ways.

Birčanin had taken the presidency of National Defence in 1932 - and had steered the association towards a more active role in national life than his predecessor Stepa Stepanović (who died in 1929). National Defence had warmly supported the dictatorship of Aleksandar, applauding his attempt to re-forge the state along Yugoslav lines - but his death and the subsequent new directions taken by the post-1934 governments of the country saw a rift open up between the leadership of National Defence, and especially Birčanin on the one hand and the government on the other. Birčanin wanted to keep the association anchored in the wartime traditions of the culture of victory and in the sphere of the Europe created at the end of the First World War. This put him and National Defence at ever greater odds with the Yugoslav government, especially during the years of Milan Stojadinovićs premiership (1935-1939). Not only did Stojadinović begin to emulate the fascist style in his own politics, he also brooked ever closer economic and political co-operation with Nazi Germany and Fascist Italy. This latter move was considered by Birčanin as a betrayal of the values for which he and his comrades had fought in the First World War, and National Defence in the latter part of the 1930s, along with other veteran organisations, such as the Association of Reserve Officers and Warriors, became an increasingly vocal opponent of the government. ${ }^{79}$ Birčanin himself was placed under surveillance by the regime, and even arrested after making a public protest against the government following the death of the Patriarch of the Serbian Orthodox Church in $1937 .{ }^{80}$ Later, Birčanin, as president of National Defence, would send a letter of sympathy to Czechoslovakia in the aftermath of the annexation of the Sudeten lands in $1939 .{ }^{81}$ His unwavering deference to the Franco-British alliances of the past earned him the attentions

\footnotetext{
79 Archive of Yugoslavia (Arhiv Jugoslavije, hereafter AJ), Fond 37 'Milan Stojadinović,' 22-260.

8 a , Fond $37,22-260$.

81 AJ, Fond 37, 22-171.
} 
of Winston Churchill's wartime British government, who hoped to cultivate National Defence and likeminded groups as a bulwark against the increasingly pro-Axis slant of the Yugoslav government. In 1941, Birčanin re-joined the fight as a Vojvoda in the 'Dinara Division' of Mihailović's Ravna Gora movement (also known as the 'Chetniks').

For Birćanin, then, the wartime alliances and traditions were to be preserved at all costs: the ballast of the new state was to be found in the wartime victory of 1914-1918, and although he and his followers had flirted with authoritarianism and even spoke favourably of certain fascist tendencies in the 1920s, the changing climate of 1930s Europe, and especially the apogee of German and Italian political and territorial revisionism, led Birčanin to cling ever more tightly to the ties of the past. In this sense, the legacy of the war inhibited National Defence from drifting wholly into the fascist sphere. Although, as we shall see, certain fringe members of the association were not so reluctant to change political course.

As has already been shown, the Chetniks were never a monolithic movement, not even under the homogenizing pressures of Aleksandar's dictatorship. Factions coalesced around charismatic leaders, Vojvode, who in turn shaped the political course of their grouping. Thus, as Birčanin held fast to the alliances of 1914-1918 as he sought orientation in the changing European political climate, so Pećanac altered the course of his faction towards the right. He had become the leading figure of the Chetnik movement after the fall of Račić and the split with Birčanin at the beginning of the 1930s, the two former allies turned rivals as the second decade of the interwar period wore on. Under Pećanac's presidency, the Chetniks of the 1930s were becoming an increasingly chauvinistic and right-wing group, critical also of the government, but turning with ever greater ferocity on non-Serbs whom, it was claimed, were undermining the project of state integration. Thus the Chetnik association of the late 1930s, as well as continuing to celebrate and commemorate the traditions of the wars of liberation and unification, also took to a kind of roving vigilantism in towns and villages of mixed ethnicity, 'protecting' the Serbian population, but also intimidating non-Serbs, especially around election time.

This provoked a counter-mobilisation on the part of the Peasant Party, many of whose members had abandoned Radić's pacifism in the wake of the killings on the parliamentary floor in 1928. Thus the 'Peasant Guard' and the 'Civic Guard' emerged as pro-Peasant Party militia groups whose intention was to protect members of the party throughout the country. Politically, these militias stood at the right-wing fringe of the new and enlarged Peasant Party of Vladko Maček, Radić's successor as party leader. They also shadowed the structure of 
the Ustashe itself: the militias emulated the organisation of Austro-Hungarian army units and were indeed staffed by Croat veterans of the imperial army. When the NDH was formed in 1941, these units were initially linked to the Ustashe's armed forces.

Pećanac, for his part, put his Chetnik units at the disposal of Milan Nedić's pro-Axis quisling 'Government of National Salvation' in 1941, serving as that regime's 'legal Chetniks' before eventually being dissolved later in the war. Pećanac had charted an unusual course in the interwar period, from a onetime candidate of the Democratic Party into a nationalist zealot at the end of the 1930s. But in Pećanac's mind violence had always been closely entwined with politics, from his affiliation with ORJUNA, to his violence at election time in the 1920s, through to his terrorizing of non-Serbs in the second-half of the 1930s. Perhaps the political and ideological components of Pećanac's programme were too desultory and semi-formed to constitute a coherent new vision of right-wing politics, but nevertheless the admiration for the fascist right and the emulation of their activities is visible. His support for the Nedić state in 1941 was in a sense the culmination of this rightwards drift.

\section{Zbor}

This last phase of the political life of the Yugoslav kingdom did produce one avowed fascist party that had roots in the war veteran movement of the 1920 . This was Zbor, the creation of Serbian politician and public figure Dimitrije Ljotić, who was himself a veteran of the wars of liberation and unification and who sought to instil the values of these conflicts into a new radical right movement committed to a Serbian-Yugoslav programme. Ljotić had served as a minister (of justice) during the dictatorship of Aleksandar, and had called on the king to push for an even more radical solution to the kingdom's political and national problems (a solution that the king rejected). Ljotić, unlike the majority of his fellow politically active war veterans and unlike the king himself, was bewitched by the rising fortunes of Italian Fascism and German National Socialism, seeing in those movements an example for emulation in Yugoslavia. Eventually Ljotić would gather into his fold right-wing leaders of various veteran and nationalist associations to form a new political party (in 1935) Združena borbena organizacija rada [Zbor; Yugoslav National Movement] - a fascist organisation with Ljotić at its head. Zbor merged Ljotićs supporters form Serbia with members of Jugoslovenska akcija [Yugoslav Action], a Yugoslav nationalist group based in Serbia and Croatia, and the Združenje borcev Jugoslavije [вој; Association of Yugoslav Combatants], a veterans' association based in Slovenia 
and comprising mainly former volunteers. ${ }^{82}$ Zbor's ideology was inspired by Italian Fascism in the strictest sense: corporatist, anti-liberal (in both the economic and political sense), anti-communist, and anti-Semitic. Its only local variations came from the religious philosophies of Nikolai Velimirović, Bishop of Žiča (an eparchy seated in Kraljevo, Serbia), a figure whom Ljotić believed offered a spiritual 'third-way' between sterile western materialism and eastern Bolshevism. ${ }^{83}$

The group did not transform politics in the way Ljotić had hoped, polling less than one percent of the vote in the elections of 1935 and 1938. Zbor was a negligible political force until the Axis occupation of Yugoslavia promoted the movement to a position of relative prominence. Ljotić himself became an influential go-between, negotiating with the occupiers and with domestic Serbian political and military forces, and heading his own militia, the Serbian Volunteer Corps.

Although Ljotić placed the war and war veterans at the centre of his fascist party, he was in the event unable to breach existing divisions within the larger veterans' groups. The associations from which he recruited were divided about Ljotić's fascist revolution, and in most cases only a right-wing fringe broke away to support him. ${ }^{84}$ This fringe included some prominent figures, such as Stanislav Krakov, who brought with him a small fraction of National Defence's membership who felt the existing veteran and nationalist associations were not going far enough to re-shape Yugoslav society. Yet most war veterans, like most voters, stayed away from Ljotić's putative right-wing revolution. Zbor was out of joint in 1930s Yugoslavia, its leader had drastically miscalculated the lure of international fascism at home, if not the scepticism towards democratic and liberal politics.

\section{Conclusion}

War veterans shaped the politics of Yugoslavia in the interwar period. Their associations saw for themselves an important role in the state-building project

82 On these groups, see Gligorijević, 'Politički pokreti i grupe s nacionalsocijalističkom ideologijom i njihova fuzija u ljotićevom zboru', in Istorijski glasnik, 4 (1965).

83 On Zbor's ideology, see Jovan Byford 'Willing Bystanders: Dimitrije Ljotić "Shield Collaboration" and the Destruction of Serbia's Jews,' In the Shadow of Hitler: Personalities of the Right in Central and Eastern Europe ed. Rebecca Haynes and Martyn Rady (London, New York: I.B. Tauris, 2011).

84 Gligorijević, 'Politički pokreti i grupe s nacionalsocijalističkom ideologijom i njihova fuzija u ljotićevom zboru.' 
after 1918, watching over political institutions and their leaders, intervening against perceived 'anti-state' forces, making temporary alliances with certain political parties and with the king in order to galvanise certain patriotic principles and ideas. In some important cases, outlined in this article, associations and their leaders brought violence directly into the political processes, terrorizing opponents, even carrying out political assassination. Authoritarian and right-wing political impulses were undeniably a factor in the veteran question after 1918. Political experimentation was brooked. Departures form the short-lived democratic norm were encouraged and supported. In the context of international fascism, however, this experimentation had limits. Perhaps because the war was typically seen by veterans as the culmination of a longerterm struggle for emancipation rather than a seminal event that harked to a new kind of politics.

As for fascism itself, in the Yugoslav case the relationship between war veterans and this political ideology can be summarised with a simple, albeit asymmetrical, formulation: fascism was not a major part of the war veteran question in interwar Yugoslavia, but war veterans were central to the identity and membership of the country's fascist groups. The two groups typically identified in the literature as fascist, the Serbian/Yugoslav movement 'Zbor' and the Croat paramilitary-terrorist organisation the 'Ustashe', stalked the margins of national and political life in Yugoslavia in the 1930s, incapable of taking power on their own meagre political resources. But war veterans were at the heart of the leadership of both organisations, and the legacy of the war years decisively shaped their political culture and programmes. And both the Ustashe and Zbor drew from a much deeper well of authoritarian, illiberal, and often violent political impulses linked to war veterans, their associations, and their supporters in the interwar period. 